\title{
CUBID EC : Aplikasi Edukasi Berbasis Android Menggunakan Augmented Reality
}

\author{
Ayyu Faridhatul Masrura ${ }^{1}$, M. Farras Aditya P. A. ${ }^{2}$, Muhammad Hussein Isron ${ }^{3}$, Dodik Arwin
} Dermawan $^{4}$, dan Paramitha Nerisafitra ${ }^{5}$

\author{
1, 2,3,4,5 Jurusan Teknik Informatika, Fakultas Teknik, Universitas Negeri Surabaya, Surabaya, Indonesia \\ e-mail:1ayyu.17051204017@mhs.unesa.ac.id, ${ }^{2}$ muhammad.17051204032@mhs.unesa.ac.id, ${ }^{3}$ muhammad.17051204065@mhs.unesa.ac.id, \\ ${ }^{4}$ dodikdermawan@unesa.ac.id,paramithanerisafitra@unesa.ac.id
}

\begin{tabular}{|c|c|}
\hline INFO ARTIKEL & ABSTRAK \\
\hline Sejarah Artikel: & Teknologi di masa kini telah menjadi penunjang setiap kebutuhan manusia. Salah satunya adalah \\
\hline Diterima 22 Mei 2020 & teknologi perangkat genggam pintar bernama smartphone. Kemampuan smartphone tidak terbatas \\
\hline Direvisi - & sebagai alat komunikasi saja, namun fitur lainnya sebagai media belajar baik secara tertulis maupun \\
\hline Disetujui 23 Mei 2020 & gambar. Modernisasi teknologi pembelajaran semakin gencar melalui teknologi-teknologi \\
\hline Dipublikasi 19 Juni 2020 & pendukung. Khususnya penerapan Augmented Reality $(A R)$ yang efektif untuk menarik minat \\
\hline \multirow{6}{*}{$\begin{array}{l}\text { Katakunci: } \\
\text { Augmented reality } \\
\text { Media pembelajaran } \\
\text { Bangunan bersejarah } \\
\text { Sejarah } \\
\text { Kebudayaan }\end{array}$} & pengguna. Melalui teknologi tersebut, kami mengembangkan media pembelajaran di bidang sejarah, \\
\hline & suatu bidang ilmu yang diharapkan tetap lestari sebagai bukti kekayaan Indonesia akan budaya dan \\
\hline & nilai sejarah di berbagai daerah. Media pembelajaran tersebut juga dapat menjadi ajang \\
\hline & $\begin{array}{l}\text { pengenalan budaya Indonesia di mata asing. Dengan nama Cubid AR, kami mengembangkan } \\
\text { aplikasi edukatif kesejarahan berbasis Android memanfaatkan teknologi AR sebagai visualisasi }\end{array}$ \\
\hline & $\begin{array}{l}\text { pembelajaran. Cubid AR berfokus pada bangunan kebudayaan yang memiliki nilai sejarah dengan } \\
\text { tujuan mengedukasi masyarakat terutama anak-anak. Diharapkan aplikasi ini dapat membantu } \\
\text { pengguna memahami budaya dan sejarah di Indonesia sehingga identitas kebudayaan tersebut } \\
\text { terdapat dikenal luas. }\end{array}$ \\
\hline & ABSTRACT \\
\hline $\begin{array}{l}\text { Keyword: } \\
\text { augmented reality } \\
\text { learning media } \\
\text { historical building } \\
\text { history } \\
\text { cultures }\end{array}$ & $\begin{array}{l}\text { Technology has become a necessity for humans. One of them that we are using is a smartphone. } \\
\text { Nowadays, we use a smartphone not only to communicate with others but also to use it as learning } \\
\text { media. Through technological support, learning media is improving its ability. Especially the } \\
\text { implementation of Augmented Reality which is capable to interest the users. Through this kind of } \\
\text { technology, we are going to develop an application of historical knowledge to prove if Indonesia is } \\
\text { rich in culture with its history. We also can introduce Indonesian cultures to foreigners through it. }\end{array}$ \\
\hline $\begin{array}{l}\text { DOI Artikel: } \\
\text { 10.35891/explorit.v12i1.2051 }\end{array}$ & $\begin{array}{l}\text { Named as Cubid EC, we develop an interactive application based on Android with AR technology } \\
\text { as the visualization of learning. It focuses on historical building with cultures that have historical } \\
\text { value for educating users, especially children. We hope the app can help users to understand } \\
\text { history with its cultures so the identity of these cultures well-known by everyone. }\end{array}$ \\
\hline
\end{tabular}

@2020 diterbitkan oleh Prodi Teknik Informatika Universitas Yudharta Pasuruan

\section{Pendahuluan}

Secara umum, Augmented Reality adalah konsep gabungan dunia fisik (objek sesungguhnya) dengan dunia digital, tanpa mengubah bentuk objek fisik tersebut [1], [2]. Konsep tersebut membawa lebih banyak informasi tentang produk dan meningkatkan visualisasi subjek. Informasi diaugmentasi ke dalam objek nyata dengan karakteristik elemen virtual atau buatan ditampilkan melalui kamera secara langsung dan realtime. Augmented Reality juga dikenal sebagai mixed reality [3], [4]. Secara definisi, Augmented Reality adalah variasi lingkungan virtual atau realita virtual yang menempatkan pengguna dalam sebuah lingkungan sintetis [5], [6]. AR telah banyak digunakan di berbagai bidang, misalnya di bidang ritel atau penjualan seperti toko online sebagai alat demo produk yang divisualisasikan secara virtual. Seperti brand fashion Zara yang meluncurkan demo produk menggunakan teknologi AR di 121 lokasi toko flagship Zara secara global dimana pelanggan dapat mengetahui bagaimana tampilan model mengenakan pakaian Zara [7]. Hal tersebut merupakan pemanfaatan teknologi virtual menggantikan produk fisik. Salah satu pemanfaatan lain konsep tersebut yakni di bidang pembelajaran. Belajar adalah suatu proses penyerapan informasi melalui alat indera melalui pengamatan serta pengalaman [8].

Di sektor pendidikan, proses pengajaran dan pembelajaran sebuah topik dapat dibuat lebih menarik. Hal tersebut diperlukan karena proses pembelajaran yang baik juga memuat aspek menyenangkan, interaktif, menantang, memotivasi dan memberi ruang lebih untuk pelajar dalam mengembangkan minat bakat [9]. Misalnya saat belajar sejarah, akan lebih menarik bila kita dapat melihat penemuan sejarah itu langsung di tempatnya. Dalam beberapa kasus, mengunjungi bangunan bersejarah atau kebudayaan sangat memakan waktu dan biaya dikarenakan faktor situs yang tersebar di berbagai lokasi. Teknologi AR dapat menjadi alternatif proses belajar tersebut dengan memvisualisasikan bangunan bersejarah ke dalam dunia nyata. Maka mempelajari sejarah di sekolah akan 
lebih menyenangkan jika objek terasa hidup di sekitar kita. Perkembangan pesat Teknologi AR menjadikan teknologi ini cukup strategis, misalnya: (1) penerapan di sektor pendidikan dalam mempelajari ilmu kimia, bahasa pemrograman, anatomi, budaya dan efek obat-obatan. (2) Dalam industri: pemasaran dan alat penjualan.

Dalam penelitian ini, peneliti ingin mengusulkan media pembelajaran dengan menerapkan teknologi AR dalam mempelajari bangunan bersejarah dengan nilai budaya, pelajar dapat menggunakan aplikasi ini untuk mempelajari objek yang diinginkan. Makalah ini menggunakan studi kasus tentang belajar sejarah menggunakan teknologi AR

\section{Metodologi Penelitian}

\subsection{Teknik Marker Based Tracking}

Teknik Marker Based Tracking merupakan salah satu teknik yang digunakan secara luas dalam pengembangan AR. Teknik ini melacak marker melalui tiga sumbu utama yakni X, Y dan Z serta bantuan titik koordinat $(0,0,0)$ secara virtual pada ruang 3 dimensi. Marker sendiri adalah gambar yang bisa dikenali melalui video gambar melalui teknologi image processing, pattern recoginition, dan computer vision. Bila marker telah terdeteksi, AR akan mendefinisikan skala yang benar melalui pose kamera. Semakin tinggi kerumitan gambar, maka semakin banyak pola yang terbentuk sehingga marker akan mudah dilacak untuk menempatkan model citra yang akan di augmentasikan [10].

\subsection{Unity $3 D$}

Unity adalah salah satu game engine lintas platform yang dikembangkan oleh Unity Technologies. Kita dapat membangun aplikasi atau game menggunakan game engine tersebut dengan software Unity 3D. Software tersebut telah dilengkapi IDE (Integrated Development Environment) menggunakan bahasa pemrograman C\# dalam script-nya. Dalam Unity 3D terdapat sebuah ekstensi dan Software Development Kit (SDK) khusus yang dapat digunakan untuk mengembangkan AR bernama Vuforia AR Extension for Unity [11].

\subsection{Vuvoria}

Vuforia adalah SDK yang mendukung pembuatan Augmented Reality pada perangkat mobile [12]. Vuforia menerapkan teknologi Computer Vision untuk melacak marker secara real time. Kemampuan tersebut memungkinkan bagi pengembang untuk menentukan posisi beserta orientasi objek virtual seperti model 3 dimensi, media video dan sebagainya untuk dapat dilihat melalui kamera perangkat mobile [13]. Vuforia akan menginisialisasikan database marker dalam package Unity. Proses inisialiasi dilakukan dengan mengunggah sejumlah gambar target atau model lainnya ke target database di portal Vuforia.

\subsection{Kebutuhan Pengguna}

Kebutuhan atau Requirement merupakan sifat-sifat sistem yang akan dikembangkan untuk disesuaikan dengan kebutuhan pengguna [14]. Kami pun melakukan sejumlah kajian untuk memperoleh solusi kebutuhan pengguna terkait media pembelajaran yang menarik dan baik sesuai kaidah pembelajaran pada umumnya. Beberapa tujuan media pembelajaran yang perlu diperhatikan dalam menampilkan objek ke bentuk tiga dimensi, antara lain:

i) Pengguna dapat mengenali objek yang ditampilkan dengan mudah dan benar

ii) Pengguna dapat terbantu mengenali objek 3D dengan deskripsi berupa suara.

iii) Pengguna mendapatkan tampilan $3 \mathrm{D}$, sesuai objek yang dipilih.

\subsection{Kebutuhan spesifikasi sistem dan implementasi}

Spesifikasi minimum perangkat yang dibutuhkan untuk mendukung penelitian ini adalah:

i) Laptop atau komputer dengan spesifikasi:

- Processor Core i3/AMD A8

- Webcam dengan resolusi minimum 320x240 pixel

- Grafis VGA Card 256 MB

- Ram 4 GB

- Hard Disk 320GB

ii) Smartphone dengan spesfikasi:

- Minimum OS Android 4.0 Ice Cream Sandwich

- Prosesor Quad Core berbasis ARM, min. $1 \mathrm{GHz}$

- GPU support for OpenGLES 2.0 (Recommended)

- Kamera 2 MP

- Mendukung Vuforia Qualcomm

Berikut ini merupakan perangkat lunak pendukung penelitian ini adalah:

- Blender (digunakan untuk membuat/mendesain objek 3D)

- Vuforia engine (digunakan untuk membuat objek marker)

- Unity 3D (digunakan untuk membuat Aplikasi Augmented Reality-AR)

- Adobe Illustrator (digunakan untuk membuat/mendesain objek gambar (*.jpeg, *.png))

- Audacity (digunakan untuk mengedit dan mengolah audio ilustrasi) 


\subsection{Metode Prancangan}

Metode perancangan diperlukan agar penelitian dapat dilakukan secara terstruktur sehingga hasil yang didapatkan sesuai dengan tujuan.

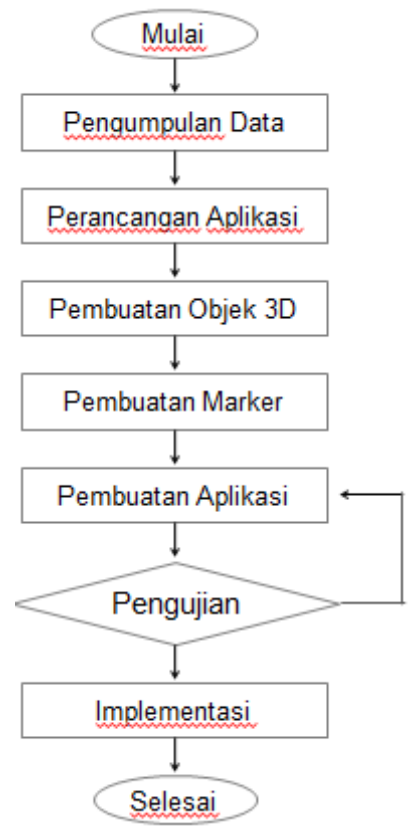

Gambar 1. Metode perancangan

Tahapan perancangan pada penelitian ini seperti Gambar 1 dengan rincian sebagai berikut:

i) Pengumpulan Data

Peneliti mengumpulkan data dengan melakukan riset secara daring mengenai bangunan bersejarah dan deskripsi singkat objek yang akan ditampilkan dalam aplikasi.

ii) Perancangan Aplikasi

Tahap perancangan aplikasi bertujuan untuk memberikan gambaran tentang perancangan dari aplikasi yang terdiri dari dua tahapan yaitu perancangan konseptual dan perancangan fisik,. Pemodelan aplikasi ini dibuat dalam bentuk diagram activity (flowchart), dan Use Case diagram.

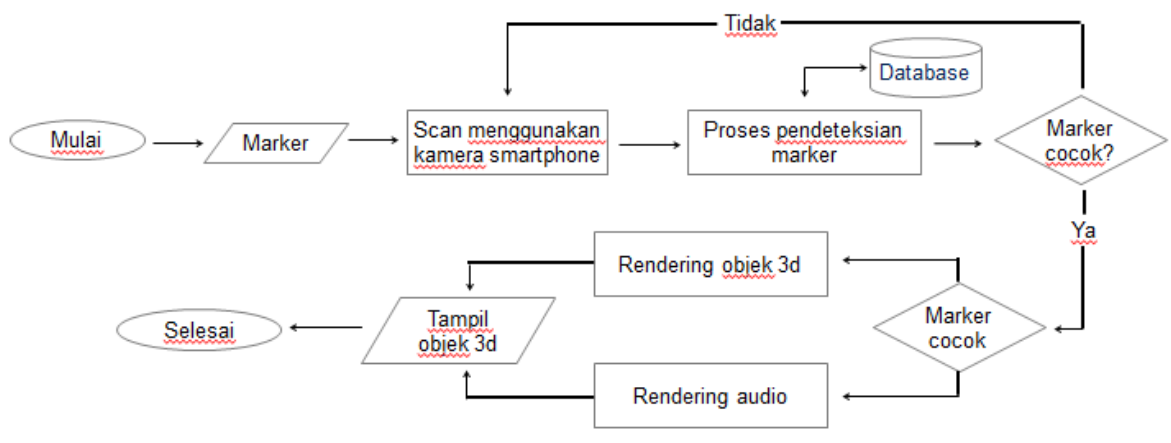

Gambar 2. Flowchart aplikasi 


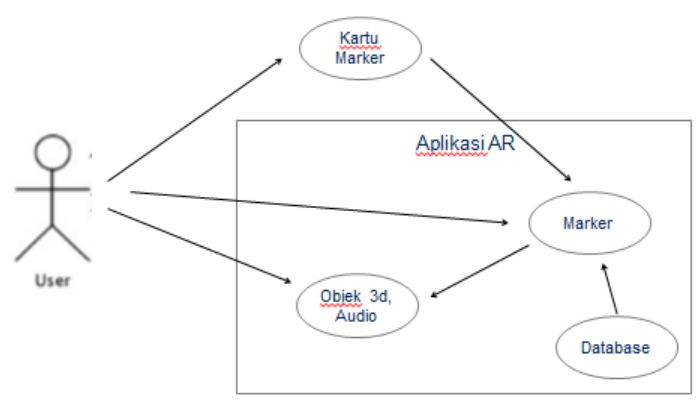

Gambar 3. Usecase diagram

iii) Pembuatan Objek 3D

Dalam aplikasi ini diperlukan objek 3D untuk ditampilkan pada smartphone. Objek 3D yang dibuat ialah bangunan bersejarah berdasarkan riset yang telah dilakukan.

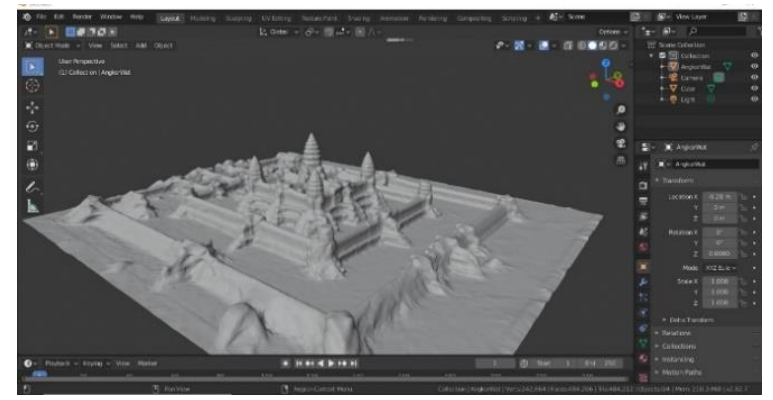

Gambar 4. Pembuatan model 3D di software Blender

iv) Pembuatan Marker

Aplikasi ini membutuhkan marker sebagai objek yang dipindai untuk menampilkan Objek 3D. Marker yang penulis gunakan adalah gambar 2D dengan format JPG. Seluruh gambar dibuat menggunakan software Adobe Illustrator. Gambar-gambar tersebut diunggah ke database Vuforia yang selanjutnya dinamakan Image Target. Sehingga marker dapat dilacak Vuforia $S D K$. Bentuk marker selain gambar bisa menggunakan opsi lain seperti data matrix code dan QR Code [15].

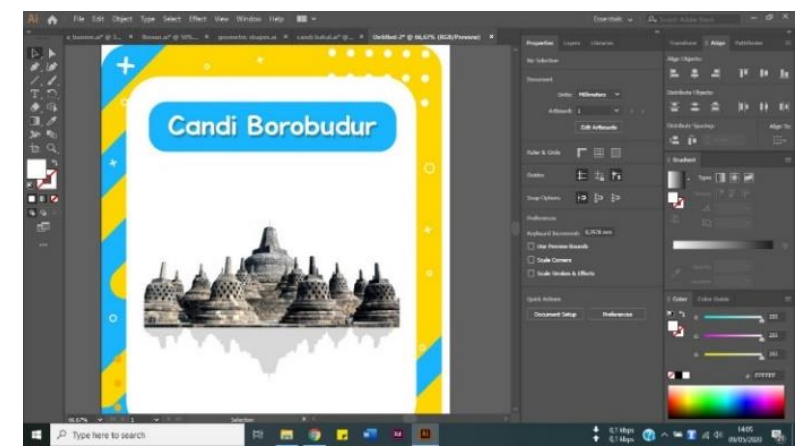

Gambar 5. Pembuatan gambar 2d di software Adobe Illustrator

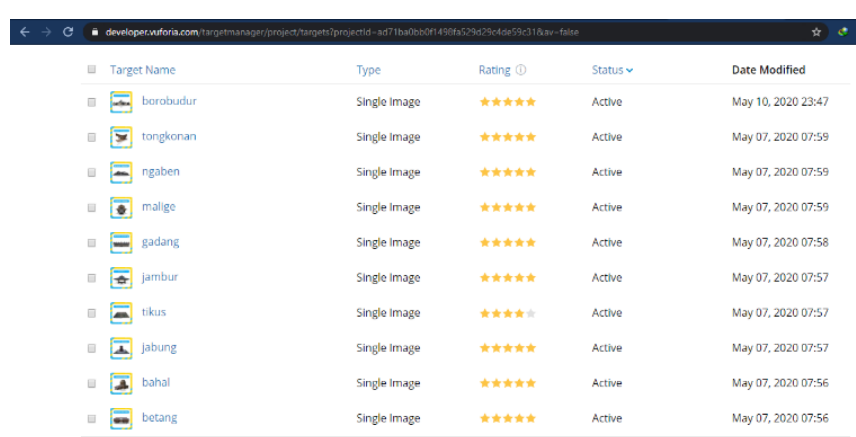

Gambar 6. Pengunggahan gambar menjadi marker pada database vuforia

v) Pembuatan Aplikasi 
Pada pembuatan aplikasi ini peneliti menggunakan software Unity. Dimana Objek 3D digabungkan dalam sebuah aplikasi berbasis android dengan bantuan software Unity.

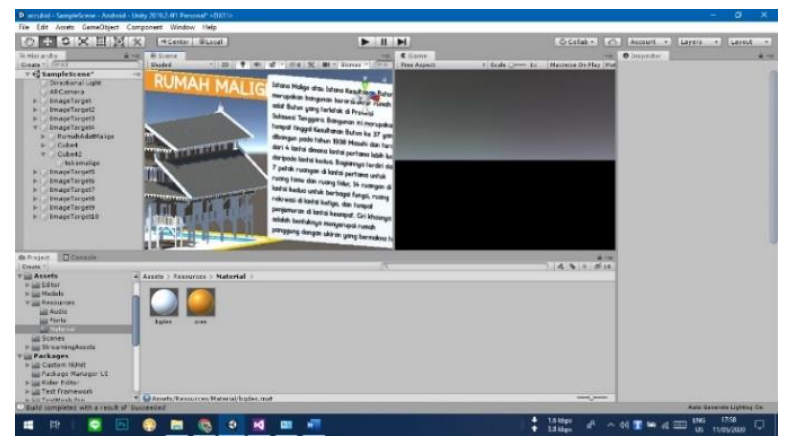

Gambar 7. Pembuatan aplikasi melalui Unity 3D

\section{vi) Pengujian}

Pengujian aplikasi menggunakan metode Blackbox testing untuk menguji fungsionalitas aplikasi.

vii) Implementasi

Merupakan tahap terakhir dimana aplikasi dapat diterapkan secara komersial dan langsung setelah melalui proses pengujian.

\section{Hasil Uji Coba Dan Pembahasan}

\subsection{Pembahasan Program}

Aplikasi ini dibuat menggunakan software Unity 3D dengan ekstensi Vuforia untuk menginisialisasikan marker beserta objek 3D menjadi media Augmented Reality. Pemberian script dilakukan pada beberapa elemen yang membutuhkan seperti penambahan audio deskripsi.

a) Tampilan Aplikasi

Halaman Menu

Apabila aplikasi dijalankan, maka scene pertama yang ditampilkan adalah Main Menu. Tombol Play untuk mulai bermain dan Exit untuk keluar.

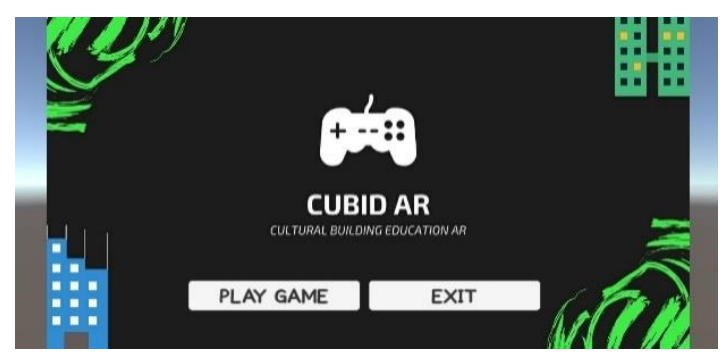

Gambar 8. Menu utama

- Halaman Kamera

Pada scene ini ditampilan viewfinder kamera smartphone yang telah terintegrasi dengan aplikasi sebagai pemindai marker yang telah diinisialisasikan melalui Vuforia. Bila marker berhasil ditemukan, maka objek 3D akan ditampilkan berdasarkan marker yang dipindai.

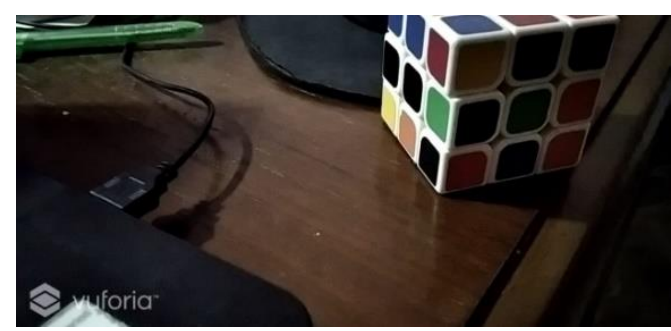

Gambar 9. Kamera sebagai pemindai marker

- $\quad$ Tampilan ketika marker ditemukan

Bila kamera menemukan marker, maka akan ditampilkan objek terkait berupa model 3D dan audio. Model 3D yang ditampilkan berupa bangunan terkait, papan nama bangunan yang mengambang, serta deskripsi bangunan di samping kanan bangunan. 


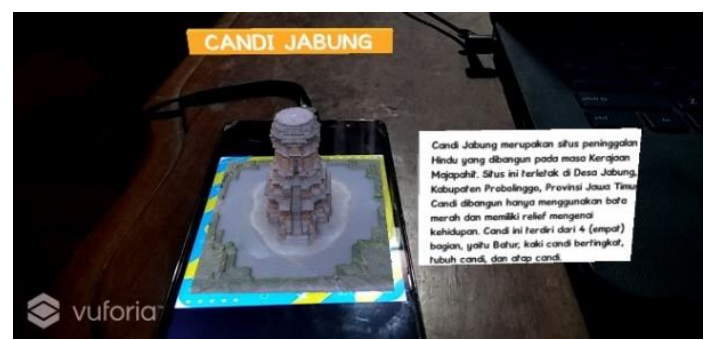

Gambar 10. Model 3D yang ditampilkan

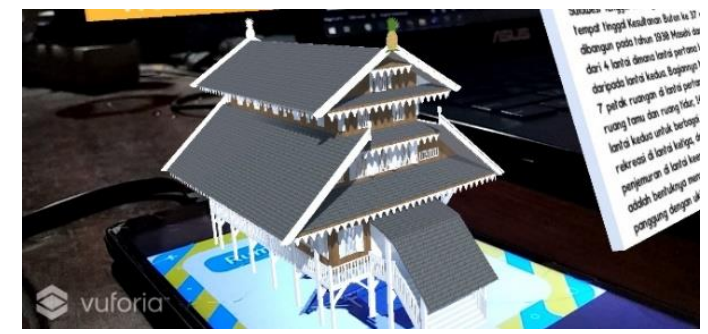

Gambar 11. Model 3D yang ditampilkan dari sisi samping

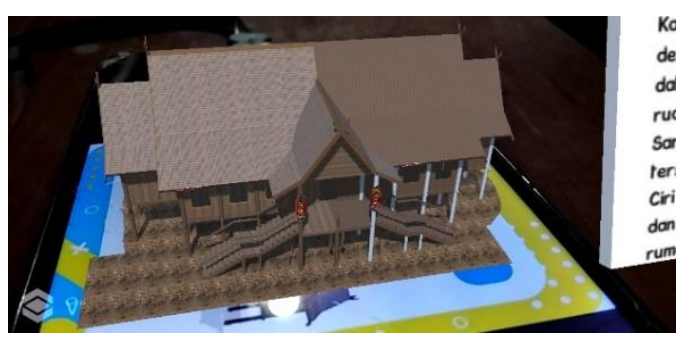

Gambar 12. Model 3D yang ditampilkan lebih dekat

b) Pengujian Aplikasi

Pengujian ini bertujuan mengetahui tingkat keberhasilan penerapan Augmented Reality pada aplikasi. Dengan hasil pengujian adalah sebagai berikut :

Tabel 1: Pengujian Aplikasi

\begin{tabular}{|c|c|c|c|}
\hline No & Uji coba & $\begin{array}{l}\text { Hasil yang } \\
\text { diharapkan }\end{array}$ & Hasil pengujian \\
\hline 1 & $\begin{array}{l}\text { Memindai marker } \\
\text { objek Borobudur }\end{array}$ & $\begin{array}{l}\text { Menampilkan } \\
\text { model 3D } \\
\text { Borobudur, } \\
\text { papan nama, dan } \\
\text { deskripsi beserta } \\
\text { audionya }\end{array}$ & $\begin{array}{l}\text { Seluruh model 3D } \\
\text { terkait Borobudur } \\
\text { muncul diatas } \\
\text { marker dengan } \\
\text { audio }\end{array}$ \\
\hline 2 & $\begin{array}{l}\text { Memindai marker } \\
\text { objek Rumah } \\
\text { Tongkonan }\end{array}$ & $\begin{array}{l}\text { Menampilkan } \\
\text { model 3D } \\
\text { Rumah } \\
\text { Tongkonan, } \\
\text { papan nama, dan } \\
\text { deskripsi beserta } \\
\text { audionya } \\
\end{array}$ & $\begin{array}{l}\text { Seluruh model 3D } \\
\text { terkait Rumah } \\
\text { Tongkonan } \\
\text { muncul diatas } \\
\text { marker dengan } \\
\text { audio }\end{array}$ \\
\hline 3 & $\begin{array}{l}\text { Memindai marker } \\
\text { objek Tempat } \\
\text { Ngaben }\end{array}$ & $\begin{array}{l}\text { Menampilkan } \\
\text { model 3D } \\
\text { Tempat Ngaben, } \\
\text { papan nama, dan } \\
\text { deskripsi beserta } \\
\text { audionya } \\
\end{array}$ & $\begin{array}{l}\text { Seluruh model 3D } \\
\text { terkait Tempat } \\
\text { Ngaben muncul } \\
\text { diatas marker } \\
\text { dengan audio }\end{array}$ \\
\hline 4 & $\begin{array}{l}\text { Memindai marker } \\
\text { objek Rumah } \\
\text { Malige }\end{array}$ & $\begin{array}{l}\text { Menampilkan } \\
\text { model 3D } \\
\text { Rumah Malige, } \\
\text { papan nama, dan } \\
\text { deskripsi beserta } \\
\text { audionya }\end{array}$ & $\begin{array}{l}\text { Seluruh model 3D } \\
\text { terkait Rumah } \\
\text { Malige muncul } \\
\text { diatas marker } \\
\text { dengan audio }\end{array}$ \\
\hline
\end{tabular}




\begin{tabular}{|c|c|c|c|}
\hline 5 & $\begin{array}{l}\text { Memindai marker } \\
\text { objek Rumah } \\
\text { Gadang }\end{array}$ & $\begin{array}{l}\text { Menampilkan } \\
\text { model 3D } \\
\text { Rumah Gadang, } \\
\text { papan nama, dan } \\
\text { deskripsi beserta } \\
\text { audionya }\end{array}$ & $\begin{array}{l}\text { Seluruh model 3D } \\
\text { terkait Rumah } \\
\text { Gadang muncul } \\
\text { diatas marker } \\
\text { dengan audio }\end{array}$ \\
\hline 6 & $\begin{array}{l}\text { Memindai marker } \\
\text { objek Rumah } \\
\text { Betang }\end{array}$ & $\begin{array}{l}\text { Menampilkan } \\
\text { model 3D } \\
\text { Rumah Betang, } \\
\text { papan nama, dan } \\
\text { deskripsi beserta } \\
\text { audionya }\end{array}$ & $\begin{array}{l}\text { Seluruh model 3D } \\
\text { terkait Rumah } \\
\text { Betang muncul } \\
\text { diatas marker } \\
\text { dengan audio }\end{array}$ \\
\hline 7 & $\begin{array}{l}\text { Memindai marker } \\
\text { objek Jambur }\end{array}$ & $\begin{array}{l}\text { Menampilkan } \\
\text { model 3D } \\
\text { Jambur, papan } \\
\text { nama, dan } \\
\text { deskripsi beserta } \\
\text { audionya }\end{array}$ & $\begin{array}{l}\text { Seluruh model 3D } \\
\text { terkait Jambur } \\
\text { muncul diatas } \\
\text { marker dengan } \\
\text { audio }\end{array}$ \\
\hline 8 & $\begin{array}{l}\text { Memindai marker } \\
\text { objek Candi Tikus }\end{array}$ & $\begin{array}{l}\text { Menampilkan } \\
\text { model 3D Candi } \\
\text { Tikus, papan } \\
\text { nama, dan } \\
\text { deskripsi beserta } \\
\text { audionya } \\
\end{array}$ & $\begin{array}{l}\text { Seluruh model 3D } \\
\text { terkait Candi } \\
\text { Tikus muncul } \\
\text { diatas marker } \\
\text { dengan audio }\end{array}$ \\
\hline 9 & $\begin{array}{l}\text { Memindai marker } \\
\text { objek Candi } \\
\text { Jabung }\end{array}$ & $\begin{array}{l}\text { Menampilkan } \\
\text { model 3D Candi } \\
\text { Jabung, papan } \\
\text { nama, dan } \\
\text { deskripsi beserta } \\
\text { audionya }\end{array}$ & $\begin{array}{l}\text { Seluruh model 3D } \\
\text { terkait Candi } \\
\text { Jabung muncul } \\
\text { diatas marker } \\
\text { dengan audio }\end{array}$ \\
\hline 10 & $\begin{array}{l}\text { Memindai marker } \\
\text { objek Candi Bahal }\end{array}$ & $\begin{array}{l}\text { Menampilkan } \\
\text { model 3D Candi } \\
\text { Bahal, papan } \\
\text { nama, dan } \\
\text { deskripsi beserta } \\
\text { audionya }\end{array}$ & $\begin{array}{l}\text { Seluruh model 3D } \\
\text { terkait Candi } \\
\text { Bahal muncul } \\
\text { diatas marker } \\
\text { dengan audio }\end{array}$ \\
\hline
\end{tabular}

\section{Kesimpulan}

Seluruh tahapan dalam pengembangan aplikasi Cubid AR telah dilalui sejak tahap perancangan hingga tahap pengujian. Dengan berakhirnya seluruh tahap, maka bisa diperoleh beberapa kesimpulan terkait pengembangan aplikasi ini :

i) CUBID AR merupakan aplikasi berbasis android di bidang pendidikan yang memanfaatkan teknologi AR (Augmented Reality) sebagai visualisasi dalam proses pembelajaran. Dengan fokus pembelajaran di bidang sejarah dan budaya dengan objek bangunan.

ii) Penerapan AR mengakomodasi pengguna melalui tampilan 3D yang dipadukan dengan audio deskripsi agar mudah dipelajari dan dipahami. Sehingga pengalaman yang diperoleh tak hanya visual, namun juga pengalaman auditori.

iii) Teknik Marker Based Tracking melalui Vuforia memberikan hasil yang optimal dalam pemindaian marker dan penampilan objek. Penerapan teknik tersebut berjalan efektif dan efisien karena tingginya respon aplikasi terhadap marker.

Berdasarkan beberapa kesimpulan tersebut, penulis meyakini bahwa aplikasi ini dapat menjadi sarana yang efektif sebagai alternatif pembelajaran sejarah dan kebudayaan yang modern dan terkini. Aplikasi ini masih diperlukan pengembangan dan saran-saran untuk penyempurnaan di masa mendatang. Maka akan lebih baik apabila ada penelitian terkait yang menyempurnakan penerapan teknologi ini khususnya menggunakan teknik marker based tracking. Beberapa saran yang bisa dipertimbangkan yaitu :

1. Aplikasi ini membutuhkan bantuan markup yang diaplikasikan dalam kartu. Penggunaan kartu juga akan meningkatkan daya tarik pengguna untuk mencoba teknologi AR. Sehingga aplikasi ini diharapkan membantu masyarakat terutama anak-anak untuk memahami sejarah dan kebudayaan di Indonesia dan dikenal luas di mata asing.

2. Penerapan Augmented Reality melalui tools/ekstensi/plugin AR lainnya seperti ARCore, AR Toolkit dan sebagainya untuk mengembangkan media AR. Sehingga setiap hasil dari masing-masing ekstensi tersebut dapat dibandingkan satu sama lain untuk memperoleh pengalaman terbaik dalam menggunakan AR.

\section{Daftar Pustaka}

[1] N. Saurina, "Pengembangan Media Pembelajaran untuk Anak Usia Dini menggunakan Augmented Reality," Jurnal IPTEK, vol. 20, no. 1, hlm. 95-108, Jun 2016, doi: 10.31284/j.iptek.2016.v20i1.27. 
[2] T. Hidayat, "Penerapan Teknologi Augmented Reality Sebagai Model Media Edukasi Kesehatan Gigi Bagi Anak," Creative Information Technology Journal, vol. 2, no. 1, hlm. 77-92, 2014.

[3] A. Katiyar, K. Kalra, dan C. Garg, "Marker based augmented reality," Advances in Computer Science and Information Technology (ACSIT), vol. 2, no. 5, hlm. 441-445, 2015.

[4] P. Milgram dan F. Kishino, "A taxonomy of mixed reality visual displays," IEICE TRANSACTIONS on Information and Systems, vol. 77, no. 12, hlm. 1321-1329, 1994.

[5] R. T. Azuma, "A Survey of Augmented Reality," Presence: Teleoperators and Virtual Environments, vol. 6, no. 4, hlm. 355385, Agu 1997, doi: 10.1162/pres.1997.6.4.355.

[6] L. Kamelia, "Perkembangan Teknologi Augmented Reality Sebagai Media Pembelajaran Interaktif Pada Mata Kuliah Kimia Dasar," Jurnal Istek, vol. 9, no. 1, 2015.

[7] H. Pranoto dan F. M. Panggabean, "Increase The Interest In Learning By Implementing Augmented Reality: Case studies studying rail transportation.," Procedia Computer Science, vol. 157, hlm. 506-513, Jan 2019, doi: 10.1016/j.procs.2019.09.007.

[8] D. A. Manaek, Nurhayati, dan Syahrir, "Rancang Bangun Augmented Reality Pada Pembelajaran Biologi Sintesis Protein Berbasis Android," dipresentasikan pada Seminar Nasional Teknik Elektro dan Informatika (SNTEI), 2018.

[9] I. Mustaqim, "Pengembangan Media Pembelajaran berbasis Augmented Reality," Jurnal Edukasi Elektro, vol. 1, no. 1, Art. no. 1, Agu 2017, doi: 10.21831/jee.v1i1.13267.

[10] S. Siltanen, "Theory and applications of marker-based augmented reality: Licentiate thesis," Thesis, VTT Technical Research Centre of Finland, 2012.

[11] L. W. Shang, M. H. Zakaria, dan I. Ahmad, "Mobile phone augmented reality postcard," Journal of Telecommunication, Electronic and Computer Engineering (JTEC), vol. 8, no. 2, hlm. 135-139, 2016.

[12] I. B. M. Mahendra, "Implementasi Augmented Reality (AR) Menggunakan Unity 3D Dan Vuporia Sdk," Dari https://ojs. unud. ac. id/index. php/jik/article/view/26341, 2016.

[13] S. Lorena Br Ginting dan F. Sofyan, "Aplikasi pengenalan alat musik tradisional Indonesia menggunakan metode based Marker Augmented Reality berbasis Android," Thesis, UNIKOM, 2018.

[14] A. Saputra, "Kajian Kebutuhan Perangkat Lunak untuk Pengembangan Sistem Informasi dan Aplikasi Perangkat Lunak Buatan LAPAN Bandung," Berita Dirgantara, vol. 13, no. 2, Art. no. 2, 2012, Diakses: Okt 31, 2020. [Daring]. Tersedia pada: http://jurnal.lapan.go.id/index.php/berita_dirgantara/article/view/1700.

[15] N. Avysa dan M. I. Rosadi, "Aplikasi Pengenalan Dinosaurus Dengan Animasi 3D Berbasis Android Menggunakan Augmented Reality (AR)," JURNAL EXPLORE IT, vol. 11, no. 2, 2019. 